\title{
Oestrogen Receptor a Localisation in the Prefrontal Cortex of Three Mammalian Species
}

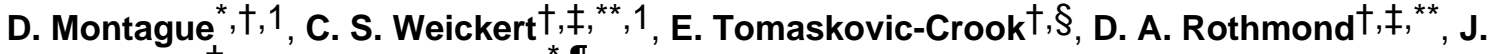 \\ E. Kleinman ${ }^{\dagger}$, and D. R. Rubinow ${ }^{*}, \boldsymbol{\uparrow}$ \\ "Behavioural Endocrinology Branch, National Institute of Mental Health, Bethesda, MD, USA. \\ ${ }^{\dagger}$ Clinical Brain Disorders Branch, National Institute of Mental Health, Bethesda, MD, USA. \\ ¥Prince of Wales Medical Research Institute, Barker and Easy Streets, Randwick, NSW, Australia. \\ §University of Melbourne, Ludwig Institute of Cancer Research, Melbourne, Vic., Australia. \\ IUniversity of North Carolina, Department of Psychiatry, Chapel Hill, NC, USA. \\ ${ }^{* *}$ Schizophrenia Research Institute, Sydney, Australia.
}

\begin{abstract}
Oestrogen modulates cognitive function and affective behaviours subserved by the prefrontal cortex (PFC). Identifying and localising oestrogen receptor (ER) $\alpha$, in human PFC will contribute to our understanding of the molecular mechanism of oestrogen action in this region. Inferences about the site of action of oestrogen in human brain are derived largely from studies performed in nonhuman mammalian species; however, the congruence of findings across species has not been demonstrated. Furthermore, the laminar, cellular, and subcellular localisation of ER $\alpha$ in the cortex is debated. Therefore, we compared the distribution of ER $\alpha$ in human dorsolateral prefrontal cortex (DLPFC) with that of monkey DLPFC and rat medial PFC. Immunohistochemistry performed on frontal cortex from the three species demonstrated ER $\alpha$ positive cells throughout all layers of the PFC, in pyramidal and nonpyramidal neurones, with both nuclear and cytoplasmic immunoreactivity. Western blot analyses and preabsorption studies confirmed that the antibody used recognised ER $\alpha$ and not ER $\beta$. A strong ER $\alpha$ immunoreactive band corresponding to the full-length ER $\alpha$ protein $(65-67 \mathrm{kDa})$ in the frontal cortex of all three species matched the size of the predominant immunoreactive band detected in breast cancer cell lines known to express ER $\alpha$. Additionally, other ER $\alpha$ immunoreactive proteins of varying molecular weight in breast cancer cells, rat ovary and mammalian brain were detected, suggesting that ER $\alpha$ may exist in more than one form in the mammalian frontal cortex. The present study provides evidence that ER $\alpha$ protein exists in neurones in mammalian PFC and that $\mathrm{ER} \alpha$ is anatomically well-positioned to directly mediate oestrogen action in these neurones.
\end{abstract}

\section{Keywords}

oestrogen receptor; brain; human post-mortem; monkey; rat

Early studies of the effects of oestrogen on the central nervous system focused largely on the hypothalamus, given the role of oestrogen in the regulation of reproduction (1). In the past two

(C) 2008 The Authors. Journal Compilation (C) 2008 Blackwell Publishing Ltd

Correspondence to: Cynthia S. Weickert, Schizophrenia Research Institute, MacQuarie Group Chair, Prince of Wales Medical Research Institute, Barker and Easy Streets, Randwick, NSW 2031, Australia (e-mail: E-mail: c.weickert@ powmri.edu.au).

${ }^{1}$ Both authors contributed equally to this work. 
decades, a number of studies have shown that oestrogen and its receptors are located in diverse brain regions and have functions within the mammalian cortex outside of areas directly involved in reproduction (2-4). A range of cognitive processes are modulated by oestrogen, including working memory $(5,6)$. The prefrontal cortex (PFC) plays a critical role in working memory and executive function (e.g. planning, problem solving, behavioural inhibition), in maintaining representations of stimuli over time to guide behaviour, and in interpreting affective valence and motivational context (7). Several studies suggest that oestrogen or oestrogen-like components modulate human dorsolateral prefrontal cortex (DLPFC) activity in both males and females, as deduced from behavioural and imaging paradigms examining working memory $(6,8,9)$, although an absence of any beneficial effects of oestrogen on cognitive performance has also been found (10).

Despite the mounting clinical evidence of an effect of oestrogen on PFC cognition, it is still not clear whether oestrogen acts through the classical activation pathway via the receptors, oestrogen receptor (ER) $\alpha$ and $E R \beta$, to mediate these effects in human prefrontal cortex. ER $\alpha$ and ER $\beta$, in the absence or presence of oestrogen, can modulate the transcription of target genes (11). Seminal studies showed that the mammalian cortex can bind oestrogen $(12,13)$; however, the molecular substrate of these oestrogen-binding sites in specific areas of the cortex is still actively debated. Further adding to the complexities in delineating the role of oestrogen in cortical processes is the lack of agreement in findings about which receptor subtype is involved and about which particular brain cell type or cortical layer is directly impacted by oestrogen.

ER $\alpha$ mRNA has been detected in the monkey prefrontal cortex $(2,15)$, and localised in neurones of the human DLPFC and hippocampus (16). In the rodent PFC, ER $\alpha$ mRNA is expressed at low levels throughout the cerebral cortex but is more pronounced in deeper layers $\mathrm{V}$ and VI (17). The existence of cortical ER $\alpha$ mRNA suggests that ER $\alpha$ protein should be present in frontal cortical neurones; however, considerable controversy regarding the abundance and the cellular localisation of cortical ER $\alpha$ protein exists. Additionally, it has been shown that there are a number of ER $\alpha$ mRNA exon-deleted variants within the frontal cortex that could potentially produce different ER $\alpha$ proteins with altered functions (18). These ER $\alpha$ mRNA variants translate into ER $\alpha$ variant proteins with distinct cellular localisations and thereby could impact the biological response of cortical neurones to oestrogen (19). These ER $\alpha$ variant proteins may also differ in their ability to be recognised by different antibodies depending on epitope recognition site, further complicating the interpretation of the presence of ER $\alpha$ via immunodetection.

To determine whether ER $\alpha$ protein could be a molecular mediator of oestrogen action in human prefrontal cortex neurones, and whether apparent species variations in the cortical localisation of ER $\alpha$ are due to methodological differences or true species differences, we asked the following questions: (i) can we detect neuronal ER $\alpha$ protein in the human, monkey and rodent PFC using the same methodology; (ii) is the anatomical distribution/expression comparable among these three species; and (iii) do the molecular weights of ER $\alpha$ immunoreactive bands vary among these three species? Understanding whether oestrogen can act directly on neurones within the DLPFC via ER $\alpha$, will impact our current models of the molecular mechanisms of oestrogen action in cortex and may help uncover novel pathways for pharmacological intervention in disorders of executive function and emotional processing.

\section{Materials and methods}

\section{Brain collection}

Experiments were performed on brains from male subjects of three species: rat $(\mathrm{n}=5$, SpragueDawley, mean age $=90$ days $)$, nonhuman primate $(n=5$, Macaca mulatta, mean age $=7.5$ 
years) and human $(n=7$, nonpsychiatric subjects, mean age $=43$ years, average post-mortem interval $=21.6 \mathrm{~h}$ ). The tissue collected from the subjects used was obtained under an approved $\mathrm{NIMH}$ protocol for human tissue, and the animal tissue was obtained following strict adherence to the guidelines of the animal care and use committee under approved NIMH protocols. Only male subjects were used to avoid the possibility of variance imposed by differences in the amount of ER $\alpha$ as a result of varying levels of reproductive steroids in females. Rats were euthanised by $\mathrm{CO}_{2}$ gas and the brains immediately removed, chilled in ice cold saline, coronally sliced, and fresh frozen in isopentane $\left(-40^{\circ} \mathrm{C}\right)$. The nonhuman primates were anaesthetised with an overdose of sodium pentobarbital and transcardially perfused with 11 of $0.9 \%$ saline. The brains were quickly removed, chilled in ice cold saline, cut into 1-cm coronal slabs, and fresh frozen in isopentane $\left(-40^{\circ} \mathrm{C}\right)$. In both species, the tissue was stored frozen $\left(-80^{\circ} \mathrm{C}\right)$ until cryostat processing.

Post-mortem human brains were obtained and organised under the authorities of the Office of the Chief Medical Examiner in Washington, DC and the Clinical Brain Disorders Branch of the National Institute of Mental Health (NIMH, Bethesda, MD, USA). Briefly, after autopsy retrieval, the brain was chilled in wet ice, coronally sliced into slabs approximately $1 \mathrm{~cm}$ in thickness, quickly frozen in a slurry of isopentane and dry ice $\left(-40{ }^{\circ} \mathrm{C}\right)$, then stored frozen at $-80{ }^{\circ} \mathrm{C}$ until cryostat processing (20). For cryostat-sectioning from blocks of normal human brain, tissue was dissected from the middle frontal gyrus (for human subject characteristics, see Table 1). For a comparison of ER $\alpha$ staining patterns across the brain, we simultaneously stained tissue from the prefrontal cortex, our region of interest, along with frozen sections from normal human mesial temporal lobe blocked at the mid-body of the hippocampus, a region known to express high levels of $\operatorname{ER} \alpha(n=2$, nonpsychiatric subjects, mean age $=64$ years, average post-mortem interval $=30.3 \mathrm{~h}$ ) and the lateral cerebellar hemisphere blocked parallel to the vermis containing follia of the cerebellar cortex, a region known to express low levels of $\operatorname{ER} \alpha(n=2$, nonpsychiatric subjects, mean age $=43$ years, average post-mortem interval $=$ $20.5 \mathrm{~h}$ ). All blocks were cut coronally at $14 \mu \mathrm{m}$, thaw-mounted on gelatine-coated slides, and stored at $-80{ }^{\circ} \mathrm{C}$.

\section{Area of analysis}

The region of interest for this study is Brodmann's area 46 (BA46) of the DLPFC in human and monkey (Fig. 1A, B) because it is integral to working memory. BA46 was defined using Nissl-stained sections based on established cytoarchitectural criteria. Briefly, BA46 is defined as: (i) the presence of a well-defined granular layer IV; (ii) columnar arrangement of pyramidal neurones in layer III; (iii) an increase in size of pyramidal neurones from superficial layer III to deep layer III; (iv) a similar size of pyramidal neurones in deep layer III and layer V; and (v) a clear transition from layer VI to the white matter. BA46 is not clearly delineated in the rat therefore we chose to examine part of the medial prefrontal cortex, the infralimbic region and cingulate cortex areas 1 and 3 (Fig. 1C). The brain regions that loosely define the prefrontal cortex in the rat are based on their neuronal connections to the mediodorsal thalamic nuclei (e.g., the anterior cingulate, agranular insular, orbitofrontal area, the medial precentral area, and infralimbic region).

\section{Primary anti-ERa antibody}

We chose to use mouse anti-human ER $\alpha$ monoclonal antibody, ER6F11 (Novocastra Laboratories, Newcastle upon Tyne, UK) as the primary antibody. The antibody binds to an epitope at the $\mathrm{N}$-terminus of the ER protein between amino acids 1-184, produces robust labelling in fresh frozen human tissues (21), and will detect ER protein of other species including monkey, rabbit, rat, mouse and quail (per Novocastra). In addition, we performed several experiments to provide a more detailed characterisation of this antibody in brain. We tested a series of antibody dilutions in the range $1: 20$ to $1: 100$, as recommended by the 
manufacturer, to determine the antibody concentration necessary to produce a reliable stain in fresh frozen human DLPFC and mesial temporal lobe tissue. A fairly high concentration is needed to attain a robust immunoreaction in our protocol (see below). To validate the ER $\alpha$ labelling pattern seen with the Novocastra antibody, a second ER $\alpha$ antibody, Santa Cruz Biotechnology's H-184 (sc-7202; Santa Cruz, CA, USA), a rabbit polyclonal raised against amino acids $2-185$ of ER $\alpha$ of human origin and recommended for detection of oestrogen receptor of mouse, rat and human origin, was tested via immunohistochemistry in human DLPFC at a dilution of $1: 40$ (recommended $1: 50$ ). To further test the specificity of the ER6F11 antibody, we incubated full-length, human recombinant ER proteins, ER $\alpha$ or ER $\beta$, with the primary antibody prior to immunolabelling. To ensure that both antibody and recombinant proteins were adequate for detection of the species used, we also performed a sequence alignment between human, macaque and rat, and found that there is a $99.4 \%$ sequence homology between human and macaque and $84.2 \%$ homology between human and rat (see Preabsorption study). Finally, we determined the specificity of the antibody for ER $\alpha$ by performing western blotting techniques with recombinant ER $\alpha$ versus ER $\beta$ proteins and by immunoprecipitation experiments (see Immunoprecipitation and Western blot analysis studies).

\section{Immunohistochemistry}

Slide-mounted tissues from all three species were thawed for $20 \mathrm{~min}$ at room temperature (RT), then fixed in 4\% paraformaldehyde [in phosphate-buffered saline (PBS), $1 \mathrm{~m}_{\mathrm{M}} \mathrm{NaOH}, 12 \mathrm{~m}_{\mathrm{M}}$ $\mathrm{NaH}_{2} \mathrm{PO}_{4}, 154 \mathrm{~mm} \mathrm{NaCl}, \mathrm{pH} 7.4$ ] for $10 \mathrm{~min}$ at room temperature. Slides were rinsed $3 \times 5$ min with PBS and placed in $75 \% \mathrm{MeOH}+0.75 \% \mathrm{H}_{2} \mathrm{O}_{2}$ solution for 20 min at RT to block endogenous peroxidase activity. Slides were rinsed $(3 \times 5 \mathrm{~min})$ with PBS and incubated with $10 \%$ normal horse serum in diluent [0.05\% bovine serum albumin (BSA), $0.3 \%$ triton X-100 in PBS] for $1 \mathrm{~h}$ at RT to block nonspecific binding. ER $\alpha$ primary antibody was applied overnight at $4{ }^{\circ} \mathrm{C}$ (ER6F11 used at a $1: 20$ dilution in diluent). After rinsing $3 \times 5 \mathrm{~min}$ in PBS, slides were incubated with a horse anti-mouse IgG biotinylated secondary antibody (Vector Laboratories, Burlingame, CA, USA) at a $1: 100$ dilution in diluent for $1 \mathrm{~h}$ at RT and rinsed again $3 \times 5 \mathrm{~min}$ in PBS. For rat sections, a horse anti-mouse IgG biotinylated secondary antibody that was pre-absorbed against rat $\operatorname{IgG}(1: 100$ dilution; Vector Laboratories) was used. This secondary antibody was prepared in the same manner as the typical anti-mouse IgG antibody, with the exception that it was run over an agarose column that contains rat IgG. As a result, the final antibody stock is devoid of any anti-mouse IgG that may cross-react with rat IgG. Slides were incubated in an avidin-biotin-peroxidase complex (ABC kit; Vector Laboratories) for $1 \mathrm{~h}$ at RT and rinsed $(3 \times 5 \mathrm{~min})$ in PBS followed by incubation with 3,3'diaminobenzidine (DAB; Sigma, St Louis, MO, USA) (12 mм final concentration in PBS with $\left.0.003 \% \mathrm{H}_{2} \mathrm{O}_{2}\right)$, for 5-7 min to visualise ER $\alpha$ labelling. The slides were rinsed $(2 \times 5 \mathrm{~min}$ in PBS), dehydrated, stained with Nissl (1.5 min exposure to $0.02 \%$ thionin), and coverslipped.

\section{Western blot analysis}

\section{Protein extraction method to yield the cytoplasmic fraction of homogenised prefrontal cortex-Frozen prefrontal cortical tissue from human, monkey and rat was} pulverised on dry ice and pre-weighed at approximately $0.5 \mathrm{~g}$. Tissue was homogenised with 10 strokes of a Dounce homogeniser in $5 \times \mathrm{vol} / \mathrm{wt}$ ice cold low salt lysis buffer $\left[5 \mathrm{~m}_{\mathrm{M}} \mathrm{NaCl}\right.$, $20 \mathrm{~m}_{\mathrm{M}}$ HEPES (pH 7.9), $1.5 \mathrm{~m}_{\mathrm{M}} \mathrm{MgCl}_{2}, 0.2 \mathrm{~m}_{\mathrm{m}}$ ethylenediaminetetraacetic acid, $0.1 \%$ Triton $\mathrm{X}-100,1 \mathrm{mM}$ dithiothreitol, $5 \mu \mathrm{g} / \mathrm{ml}$ aprotinin, $0.5 \mathrm{mg} / \mathrm{ml}$ bacitracin, $40 \mu \mathrm{g} / \mathrm{ml}$ phenylmethysulphonyl fluoride (PMSF), $5 \mu \mathrm{g} / \mathrm{ml}$ pepstatin A, $5 \mu \mathrm{g} / \mathrm{ml}$ leupeptin]. All protease inhibitors (aprotinin, pepstatin A, and leupeptin) were purchased from ICN (Aurora, OH) except bacitracin, purchased from Sigma. The homogenates were then centrifuged at 14000 $g$ for $10 \mathrm{~min}$. at $4{ }^{\circ} \mathrm{C}$, and the supernatants containing the crude, extra-nuclear (which we refer to as the 'cytoplasmic' fraction, were collected, and stored in $10 \%$ glycerol at $-80{ }^{\circ} \mathrm{C}$ whereas 
the remaining pellet containing the nuclear material was re-suspended, loaded with high salt buffer, lysed, and stored frozen as described (4). Protein concentrations from each sample were determined by spectrophotometry with a BCA protein assay kit (Pierce, Rockford, IL, USA).

SDS-PAGE and immunoblot detection-To determine the molecular weight of proteins recognised by the ER $\alpha$ primary antibody used in the immunohistochemistry experiments, we performed western blot analyses on the following preparations: (i) crude cytoplasmic fractions from rat, monkey and human brain; (ii) MCF7 breast cancer cell lysate; (iii) T47D breast cancer cell lysate; (iv) rat ovary extract (MCF7, T47D and rat ovary extracts were purchased from Santa Cruz Biotechnologies); and (v) solutions containing baculovirus system derived, human recombinant full-length ER $\alpha$ (approximately 62.80kDa; PV4543) or human recombinant fulllength ER $\beta$ (approximately 59.50kDa; PV4539), both purchased from PanVera Corp (Madison, WI, USA). Rat and monkey cytoplasmic fractions were loaded at $50 \mu \mathrm{g}$ per well; human cytoplasmic fractions were loaded at $75 \mu \mathrm{g}$ per well; MCF7, T47D and rat ovary lysates/ extracts were loaded at $50 \mu \mathrm{g}$ per well; and full-length ER $\alpha$ and ER $\beta$ proteins were loaded at $0.4 \mu \mathrm{g}$ per well. The mammalian cytoplasmic fractions and recombinant proteins were diluted to their final protein concentrations in sample buffer $(62.5 \mathrm{~m}$ Tris, $10 \%$ glycerol, $2 \%$ SDS, $0.00125 \%$ bromophenol blue, and $5 \% \beta$-mercaptoethanol). All samples were heated at $94{ }^{\circ} \mathrm{C}$ for $4 \mathrm{~min}$ and then centrifuged. The samples were separated on 7.5\% SDS-PAGE and transferred to nitrocellulose membrane (Amersham Pharmacia Biotech, Piscataway, NJ, USA) by electro-blotting. After blocking with 3\% BSA in Tris-buffered saline (TBS) and $0.1 \%$ Tween $_{20}$ (blocking buffer) overnight at $4{ }^{\circ} \mathrm{C}$, the membrane was incubated with NCL-ER6F11, the same monoclonal $1^{\circ}$ antibody used in the immunohistochemistry experiment, at a $1: 50$ dilution in blocking buffer overnight at $4{ }^{\circ} \mathrm{C}$. The membrane was subsequently washed $8 \times 5$ min in TBS, $0.1 \%$ Tween $_{20}$ (wash buffer) and then incubated with goat anti-mouse IgG peroxidase-conjugated secondary antibody (1:10 000 dilution in blocking buffer; Chemicon laboratories, Temecula, CA, USA) for $1 \mathrm{~h}$. at RT and then again washed $6 \times 5 \mathrm{~min}$ in wash buffer. Immunopositive bands were visualised using Amersham ECL plus Chemiluminescent Substrate Reagents (Piscataway, NJ, USA) and exposure to Kodak BioMax MR film (Eastman Kodak Company, Rochester, NY, USA).

\section{Preabsorption study}

To determine the specificity of the ER $\alpha$ monoclonal antibody, the antibody (ER6F11) was preincubated with recombinant full-length $\mathrm{ER} \alpha$ or $\mathrm{ER} \beta$ protein (described above). Increasing amounts of recombinant protein were added to a fixed concentration of ER $\alpha$ antibody at a 1 : $1,1: 5$ and $1: 10$ molar concentration of ER6F11 to molar concentration of full-length protein (the $1: 1$ molar concentration was defined as $3.75 \mu \mathrm{g} / \mathrm{ml}$ ER6F11 with $3.26 \mu \mathrm{g} / \mathrm{ml}$ or $2.62 \mu \mathrm{g}$ / $\mathrm{ml}$ of $\mathrm{ER} \alpha$ or $\mathrm{ER} \beta$ respectively). The mixtures were gently rotated overnight at $4{ }^{\circ} \mathrm{C}$ in diluent. The following day, the aforementioned methods for immunohistochemistry were performed on serial sections from the same individual. For semi-quantitative evaluation of the immunolabelling, sections were viewed under $\times 40$ objective on a Zeiss Axiophot microscope (Carl Zeiss MicroImaging, Inc., Thornwood, NY, USA) under constant illumination, and images were captured with a digital camera using a random start point on the middle frontal gyrus. ER $\alpha$ immunoreactivity in 20 neurones in layer $\mathrm{V}$ was determined by drawing an area of interest around the cell body and applying an optical density scale using automated counting tools from a Bioquant image analysis system (Nashville, TN, USA).

\section{Immunoprecipitation}

To further confirm the ER6F11 antibody specificity demonstrated with the western blot analysis and preabsorption study, we immunoprecipitated DLPFC protein with the ER6F11 primary antibody and probed this immunoblot with a different primary ER $\alpha$ antibody (H-184, sc-7207; Santa Cruz Biotechnologies). One hundred and fifty microgram of DLPFC protein, 
from the human brain, was pre-cleared by incubation with washed protein $\mathrm{G}$ sepharose beads in NP-40 cell lysis buffer (50 mм Tris-HCl pH 8.0, $150 \mathrm{~m}$ NaCl, $1 \%$ NP-40), PMSF (50 $\mu \mathrm{g} /$ $\mathrm{ml})$ and protease inhibitor cocktail [aprotinin $(1 \mu \mathrm{g} / \mathrm{ml})$, leupeptin $(1 \mu \mathrm{g} / \mathrm{ml})$, pepstatin $(1 \mu \mathrm{g} /$ $\mathrm{ml})]$. The DLPFC protein was incubated on ice for $1 \mathrm{~h}$ with $25 \mu \mathrm{l}$ of ER6F11 antibody. The antibody-protein complexes were immunoprecipitated overnight at $4{ }^{\circ} \mathrm{C}$, then incubated with fresh protein $\mathrm{G}$ beads, the protein was eluted and prepared for western blotting, which was carried out as described previously but with the Santa Cruz H-184 antibody at a $1: 200$ dilution.

\section{Results}

\section{ERa positive cells in the human and monkey DLPFC and rat medial PFC}

Neuronal ER $\alpha$ was detected by immunohistochemistry within the DLPFC of both humans and monkeys and in the medial PFC of rat (Fig. 2B-D). Cellular ER $\alpha$ labelling was robust throughout the cortical layers in all three species. A similar staining pattern with neuronal labelling was observed in the human DLPFC with the Santa Cruz ER $\alpha$ antibody (data not shown). In the absence of the Novo-castra ER $\alpha$ antibody, no background immunostaining was observed in human DLPFC (Fig. 2A). Comparable results were observed in the absence of primary antibody in monkey and rat prefrontal cortex (data not shown). Although the immunostaining in the PFC is robust, it is unknown how the intensity of the immunodetection relates to the absolute concentration of ER $\alpha$ protein in this region.

For humans and monkeys, strong ER $\alpha$ antibody labelling was observed in both pyramidal and nonpyramidal shaped neurones throughout layers II-VI (Fig. 2B, C). Within layer I, labelling was detectable in a small number of cells in all three species, but this labelling was fairly light. In the primates, pyramidal neurones, especially in layer V, showed strong ER $\alpha$ immunolabelling that was clearly observed in both the cytoplasm and nucleus (Fig. 3A, B). Prominent ER $\alpha$ immunoreactivity was seen in neuronal nuclei in deeper cortical layers of the rat (Fig. 3C). In both the human and the monkey cortex, the ER $\alpha$ protein distribution was found in cytoplasm and nucleus (Fig. 3D, E, black arrows). In some neurones, the nucleus was difficult to distinguish against the mottled cytoplasmic ER $\alpha$ labelling (Fig. 3F, white arrow heads). Whether distribution was predominantly cytoplasmic or apparently equally distributed, most neurones displayed punctate labelling in both areas. Intense ER $\alpha$ immunoreactivity could sometimes be found in clumps near the outer cell membrane (Fig. 3D, E, white arrowheads), or at the nuclear membrane (Fig. 3F). Additionally, in primate, ER $\alpha$ immunoreactivity extended into the apical and basilar dendrites of most neurones (Fig. 3D-F, black arrowheads). However, in the rat $\mathrm{mPFC}$, only light ER $\alpha$ immunopositive label was found in the apical dendrite (Fig. 3C). Overall, the relatively light labelling of the cytoplasm compared to the nucleus in neurones in rat $\mathrm{mPFC}$ accentuated the nuclear labelling in rodent compared with the primate. The subcellular distribution of ER $\alpha$ immunoreactivity varied from neurone to neurone. In all three species, overall ER $\alpha$ antibody labelling was lighter in the subcortical white matter and, although ER $\alpha$ immunoreactive neuropil appeared to stop abruptly at layer VI and was absent from the forceps minor of the corpus callosum in the rat, ER $\alpha$ immunopositive cells were detected in the subcortical white matter of humans (morphologically consistent with interstitial white matter neurones).

To compare immunolabelling in the human DLPFC to other brain areas, we also examined the human hippocampus, a region of abundant $\mathrm{ER} \alpha$ (22) and the cerebellum, a region of sparse ER $\alpha$ expression (23). Immunopositive neurones were found in all three brain regions (Fig. 4AC); however, as shown in previous studies on ER $\alpha$ mRNA in humans, ER $\alpha$ protein levels were fairly low in the cerebellar cortex, specifically detected in Purkinje and Golgi cells, which expressed low to moderate levels of ER $\alpha$ protein. Robust labelling of ER $\alpha$ immunopositive pyramidal neurones were found in the hippocampus as has been reported previously (22), and these neurones stained with similar intensity as pyramidal neurones in the PFC. 


\section{Western blot analysis of prefrontal cortex and cell lysate}

To confirm that the ER $\alpha$ protein localisation in PFC from the current study was specific to $E R \alpha$ and not due to ER $\beta$, western blot analyses were performed. The first western blot demonstrates the specificity of the ER $\alpha$ antibody in preparations that contain ER $\alpha$ and/or ER $\beta$ : two breast cancer cell lines (MCF7 and T47D), rat ovary and preparations of purified recombinant ER $\alpha$ and ER $\beta$. As seen in Fig. 5(A), the antibody recognised a protein band at approximately $65-67 \mathrm{kDa}$ (corresponding to the full-length ER $\alpha$ isoform) in cancer cell lysates and in rat ovary. Furthermore, the antibody recognised recombinant ER $\alpha$, but did not display any affinity for the recombinant ER $\beta$ protein (compare lane 4 to lane 5). Several molecular weight bands were recognised in addition to the expected $65-67 \mathrm{kDa}$ band in rat ovary and in breast cancer cell lines.

The second western blot assessed the size of ER $\alpha$ in cytoplasmic protein extracted from human, monkey and rat frontal cortex. As seen in Fig. 5(B), the antibody recognised a 65-67 kDa band in all three species studied. This observation supports the immunohistochemical findings; namely, that the classical ER $\alpha$ protein can exist in the cytoplasmic or extranuclear compartment of cells in all three mammalian species. In addition to detecting the predicted full-length protein in brain, several immunoreactive bands were observed above and below the reported molecular weight of $65-67 \mathrm{kDa}$ (approximately $45-48,51-55$ and $94-98 \mathrm{kDa}$ in molecular weight). The pattern of immunoreactive bands found in the mammalian frontal cortex is similar to that found in lysates from the MCF7 cell lines known to express many splice variants of ER $\alpha$ mRNA; these ER $\alpha$ splice variants are also found in normal breast and normal brain $(18,24)$.

\section{Antibody preabsorption studies with ER $\alpha$ and ER $\beta$ protein confirmed that the monoclonal antibody is specific for ERa protein(s)}

To further confirm that we were labelling ER $\alpha$ rather than ER $\beta$, we performed immunohistochemistry in human frontal cortical tissue after preabsorbing the antibody with purified ER $\alpha$ or ER $\beta$ protein (Fig. $6 \mathrm{~A}-\mathrm{C}$ ). Antibody alone produced a punctate labelling in the neurones in all layers of the prefrontal cortex (Fig. 6A). When the antibody was preabsorbed overnight with $\mathrm{ER} \alpha$ protein, antibody labelling was greatly diminished (Fig. 6B). The results from the semi-quantitative analysis of the ER $\alpha$ immunolabelling following preabsorption with $E R \alpha$ and with ER $\beta$ proteins are displayed in Fig. 6(D). With increasing concentrations of the full length ER $\alpha$ recombinant protein relative to primary antibody $(1: 1,1: 5$ and $1: 10$ molar ratio of $E R \alpha$ antibody concentration to recombinant protein concentration), the ER $\alpha$ immunolabelling was significantly decreased compared to the immunolabelling with the primary antibody alone, whereas two concentrations of ER $\beta$ recombinant protein $(1: 1$ and 1 : 10) did not significantly block anti-ER $\alpha$ antibody immunoreactivity in neurones. The diminution of the anti-ER $\alpha$ antibody signal with full-length ER $\alpha$ was significantly lower than baseline at all three concentrations of recombinant ER $\alpha$ protein and showed a linear reduction in staining up to five times the molar ratio of antigen to antibody. At a five-fold molar excess of the recombinant ER $\alpha$ protein, we found levels of antibody staining that approached a completely blocked antibody signal (approximately $80 \%$ diminished) but, at a ten-fold molar ratio, the levels of the immunoreactivity began to increase. Preabsorption with ER $\beta$ protein resulted in no diminution of ER $\alpha$ antibody labelling (Fig. 6C). Preabsorption with ER $\alpha$ protein before immunohistochemistry in rat and monkey tissue yielded similar results (data not shown).

\section{Immunoprecipitation with ER6F11 antibody confirmed that the monoclonal antibody is specific for ERa protein(s)}

To further demonstrate the specificity of the ER6F11 antibody used in our immunohistochemistry experiments, we immunoprecipitated DLPFC protein extracts with ER $\alpha$ ER6F11 then performed western blot analysis on the product with the Santa Cruz H-184 ER $\alpha$ antibody. We detected an immunopositive band at the predicted molecular weight of 
protein, approximately $65-67 \mathrm{kDa}$, suggesting that the two primary antibodies were indeed capable of recognising the same ER $\alpha$ protein in brain. In addition, other smaller immunoreactive bands were detected by the H-184 antibody after immunoprecipitation (approximately 49 and $55 \mathrm{kDa}$ ). These results provide independent evidence that the Novocastra antibody used in the present study detects at least three different forms of ER $\alpha$ in brain and are consistent with findings from our original western blot, preabsorption studies, and $\mathrm{ER} \alpha$ mRNA studies.

\section{Discussion}

Our observation of fairly abundant ER $\alpha$ immunoreactivity in cortical neurones of the mammalian PFC challenges the notion that ER $\alpha$ levels in this region are minimal or nonexistent. The high density of ER $\alpha$ immunolabelled cells found in our study contrasts with the overall sparse ER $\alpha$ protein distribution found in some studies of rodent cortex $(3,25)$. However, our results are consistent with other immunolocalisation studies in rat cortex that find abundant and widespread ER $\alpha$ protein in neurones $(4,26)$. Furthermore, the detection of ER $\alpha$ protein in the human frontal cortex supports our previous demonstration of ER $\alpha$ mRNA in the human DLPFC by northern blotting, in situ hybridisation, and nested RT-PCR followed by direct sequencing $(16,18)$. We demonstrated that ER $\alpha$ mRNA is commonly found in both pyramidal and nonpyramidal cortical neurones by in situ hybridisation (16). Although low to negligible levels of ER $\alpha$ mRNA have been reported in the rat medial PFC (17), Pau et al. (15), showed $\mathrm{ER} \alpha \mathrm{mRNA}$ expression by reverse transcriptase-polymerase chain reaction (RT-PCR) in the adult frontal cortex of rhesus macaques. In addition, expression of ER $\alpha$ mRNA and protein in BA46 of ovarectomised and oestrogen replaced female rhesus macaques was detected by in situ hybridisation and immunohistochemistry by members of our group (2). Thus, although published reports differ regarding the distribution of ER $\alpha$ protein and mRNA in mammalian brain, many studies suggest that ER $\alpha$ protein present in the cortex.

The discrepancy between our finding of robust ER $\alpha$ protein and those of previous studies showing low levels of ER $\alpha$ mRNA and protein in cortex may result from methodological differences such as antibody specificity or concentration, riboprobe sensitivity, fixative choice and tissue preparation. For example, the concentration of primary antibody used may be critical in optimising ER $\alpha$ detection in fresh frozen tissue. Another methodological point to consider is that our immunohistochemical signal is not completely blocked by pre-incubation with $\mathrm{ER} \alpha$, suggesting that other proteins similar to ER $\alpha$ may contribute to the immunoreactive signal. Alternatively, incubating the primary antibody with high levels of the full-length $\mathrm{ER} \alpha$ protein may artificially increase the background immunohistochemical signal. The ER $\alpha$ component of the anti-ER $\alpha$ : ER $\alpha$ protein complexes formed during preabsorption could be binding to other ER $\alpha$ binding partners such as steroid receptor coactivators in the tissue slice (11) and this could increase the immunohistochemical signal at higher concentrations of ER $\alpha$.

In the present study, we find robust ER $\alpha$ immunolabelling in the nucleus and cytoplasm. These results concur with earlier and recent reports of both nuclear and cytoplasmic ER $\alpha$ immunolabelling that can extend into the dendrites of brain neurones $(2,3,22)$. González et al. (27) reported ER $\alpha$ immunoreactivity in nucleus and cytoplasm of pyramidal neurones in all layers of human adult temporal cortex and Mukai et al. (27) showed that ER $\alpha$ was located in nuclei and cytoplasm within hippocampal neurones of rats. Consistent with other studies of rodent cortex $(4,26)$, we found prominent nuclear distribution of ER $\alpha$ in rat frontal cortex.

Cytoplasmic expression of ER $\alpha$ protein has been previously observed in a number of species, including humans $(28,29)$, monkey $(2)$, and rat $(30)$. Experimental studies in rodents suggest that not only is ER $\alpha$ found in the spine heads and synaptic terminals of neurones, but also that this cytoplasmic subcellular localisation is influenced by the age and the oestrogen status of the animal (31). Additionally, some variant forms of ER $\alpha$ mRNA have been detected in the 
human and monkey DLPFC by splice variant specific RT-PCR (18). Some of these braindetected variants are unable to translocate to the nucleus in transfected cells and would be expected to be exclusively cytoplasmic (19). Taken together, our results suggest that ER $\alpha$ protein can be found in both the nucleus and cytoplasm in mammalian cortex and that the $\mathrm{ER} \alpha$ protein distribution may vary from neurone to neurone within the cortex.

Our western blot analysis reveals multiple ER $\alpha$ immunoreactive bands with molecular weights that are consistent across the three species. In addition to the approximately $65 \mathrm{kDa} \mathrm{ER} \alpha$, immunopositive bands of molecular weight above and below the full-length ER $\alpha$ were also detected. The smaller immunoreactive bands at 49 and $55 \mathrm{kDa}$ found in the frontal cortex of these three species are similar to that found in lysates from the MCF7 cell lines and normal tissue known to express splice variants of ER $\alpha$ mRNA $(18,24)$. It could be argued that the appearance of smaller molecular weight bands in human DLPFC are the result of protein degradation during extended post-mortem intervals. We believe that this is not the case in the present study because the monkey and rat cortical tissues were taken quickly after euthanasia and the same ER $\alpha$ immunoreactive smaller-sized bands were also recognised. Furthermore, smaller sized ER $\alpha$ bands were seen in the cell lysate preparations with no post-mortem interval. The immunoreactivity observed in the present study therefore may represent the expression of not only the classical $\mathrm{ER} \alpha$, but also smaller variant isoforms of $\mathrm{ER} \alpha(32,33)$. Larger ER $\alpha$ immunoreactive bands between 80 and $112 \mathrm{kDa}$ have also been previously identified (28,33, 34). Various explanations may be offered for the appearance of these bands in western blots, including longer splice variants (34), formation of homo- or heterodimers (35),

phosphorylation or ubiquitination (33) and complexes of ER $\alpha$ with any of its possible binding partners (11). Thus, we may expect to see not only the classical ER $\alpha 66 \mathrm{kDa}$ immunoreactive band, but also additional isoforms.

As noted above, the identification of other isoforms or splice variants of ER $\alpha$ in native mammalian tissue is not a novel finding. Studies characterising the ER $\alpha$ gene report the production of several different mRNA transcripts in normal tissue $(18,32)$. The relevance of these alternate transcripts is suggested by observations that several of the proteins they encoded have been found in rat uterus and pituitary $(36,37)$. Some of the protein isoforms found in rat uterus and pituitary are of particular interest because they are within the size range of the $\mathrm{ER} \alpha$-like proteins identified in the present study. Furthermore, studies investigating the function of variant $E R \alpha$ isoforms in vitro $(19,38)$ suggest that the $E R \alpha$-like proteins may be physiologically meaningful and therefore, may be relevant to oestrogenic action in PFC.

In the present study, we describe ER $\alpha$ immunoreactivity in males; however, we may expect similar findings in females. Indeed, cortical ER $\alpha$ immunoreactivity appears to be similar in male and female rodents (3); sex differences were not found in cell number, intensity or distribution of ER $\alpha$ immunoreactivity in rodent hippocampus or in adult human temporal cortex (28). Additionally, our previous ER $\alpha$ mRNA studies in human PFC found no gender difference in ER $\alpha$ mRNA levels (16). Similarly, ER $\alpha$ mRNA expression in male and female rhesus macaque cortex were comparable (15) and cortical ER $\alpha$ mRNA levels do not differ by gender using real-time PCR across the first month of postnatal life in mice (39). Behaviourally, oestrogen or selective oestrogen receptor modulators appear to alter brain activation and/or enhance task performance during PFC-influenced behavioural paradigms in male and female humans $(6,8,9)$.

Although behavioural and anatomical studies have provided a basis for inferring direct oestrogen-mediated action in the PFC, the molecular mechanism for these actions (e.g. genomic versus nongenomic actions) is not fully understood. Our results suggest that neuronal $\mathrm{ER} \alpha$ constitutes a viable molecular mediator of oestrogen action in the frontal cortex of mammals. ER $\alpha$ protein was found in all layers of mammalian prefrontal cortex, prominent in 
neurones (both pyramidal and nonpyramidal) and not clearly identified in astrocytes. Using parallel methodology, we have identified prominent ER $\alpha$ immunoreactivity in the DLPFC of humans and monkeys as well as in the medial PFC of rats. Our observation confirms an earlier report that also detected robust ER $\alpha$ immunolabelling throughout the cortex and highlights the possibility that differences in methodology impact ER $\alpha$ detection in brain (4).

Although the effects of oestrogen can be mediated throughout oestrogen-sensitive neurotransmitter systems that innervate the PFC such as serotonin and dopamine (40), our detection of prominent ER $\alpha$ suggests that oestrogen can have direct effects on cortical neurones. Indeed, oestrogen can alter spine number and spine morphology in frontal cortical pyramidal neurones $(41,42)$. However, the ER responsible for mediating oestrogen action in pyramidal neurones in the primate frontal cortex was not determined in that study. The classical mechanism of action for oestrogen is via its known intracellular receptors ER $\alpha$ and ER $\beta$; either or both may be involved. In the rodent PFC, ER $\beta$ mRNA expression is detectable and could be expressed at higher levels than ER $\alpha$ mRNA $(17,25)$, although the absolute molar abundance of ER $\alpha$ and ER $\beta$ mRNA or protein in the mammalian frontal cortex is unknown. Thus, ER $\alpha$ and ER $\beta$ may co-contribute to oestrogen binding, although we cannot exclude the possibility that a novel ER transcript such as ER-X (43) or GPR30 (44) may play a role, particularly in nongenomic signalling.

The localisation of ER $\alpha$ in PFC suggests that oestrogen may work via its classical intracellular receptor (full-length and/or variant isoforms). The widespread subcellular distribution of these $\mathrm{ER} \alpha$ proteins in neurones (i.e. localised in both the cytoplasm and nucleus) suggests diverse mechanisms of action. Expression in the nucleus suggests that ER $\alpha$ could serve in the classical sense, as a transcription factor that directly modulates gene expression activity at oestrogen response elements or indirectly modulates gene activation via interaction with other transcription factors. Localisation of ER $\alpha$ outside the nucleus suggests that ER $\alpha$ may be mediating some oestrogen-induced nongenomic efforts; for example, via the cAMP or similar pathway (35). Moreover, the identification of possible ER $\alpha$ isoforms in the present study may confer very different biological effects from the full-length protein, as demonstrated in clonal cell lines (19). Future studies aimed at examining the molecular mechanism of cortical ER $\alpha$ action in various mammalian species is expected to contribute significantly to our understanding of oestrogenic action in the regulation of cognition and affect in humans.

\section{Acknowledgements}

The authors wish to thank Sarah Anastasia Benson (research assistance), Lei Zhang (rat tissue donation), Richard Saunders (monkey tissue donation), Elizabeth Tunbridge (ER $\alpha$ immunoprecipitation), and Joan E. Magnusen (organisational and writing assistance) for their kind assistance in this project. Grant sponsor and grant number: a NARSAD Young Investigator award to C.S.W. supported this work.

\section{References}

1. McEwen BS. nvited review: estrogens effects on the brain: multiple sites and molecular mechanisms. J Appl Physiol 2001;91:2785-2801. [PubMed: 11717247]

2. Wang J, Cheng CM, Zhou J, Smith A, Weickert CS, Perlman WR, Becker KG, Powell D, Bondy CA. Estradiol alters transcription factor gene expression in primate prefrontal cortex. J Neurosci Res 2004;76:306-314. [PubMed: 15079859]

3. Kritzer MF. Regional, laminar, and cellular distribution of immunoreactivity for ER alpha and ER beta in the cerebral cortex of hormonally intact, adult male and female rats. Cereb Cortex 2002;12:116128. [PubMed: 11739260]

4. Butler JA, Kallo I, Sjoberg M, Coen CW. Evidence for extensive distribution of oestrogen receptor alpha-immunoreactivity in the cerebral cortex of adult rats. J Neuroendocrinol 1999;11:325-329. [PubMed: 10320558] 
5. Rapp SR, Espeland MA, Shumaker SA, Henderson VW, Brunner RL, Manson JE, Gass ML, Stefanick ML, Lane DS, Hays J, Johnson KC, Coker LH, Dailey M, Bowen D. Effect of estrogen plus progestin on global cognitive function in postmenopausal women: the Women's Health Initiative Memory Study: a randomized controlled trial. JAMA 2003;289:2663-2672. [PubMed: 12771113]

6. Keenan PA, Ezzat WH, Ginsburg K, Moore GJ. Prefrontal cortex as the site of estrogen's effect on cognition. Psychoneuroendocrinology 2001;26:577-590. [PubMed: 11403979]

7. Kane M, Engle R. The role of prefrontal cortex in working memory capacity, executive attention, and general fluid intelligence: an individual-differences perspective. Psychon Bull Rev 2002;9:637-671. [PubMed: 12613671]

8. Goekoop R, Barkhof F, Duschek EJ, Netelenbos C, Knol DL, Scheltens P, Rombouts SA. Raloxifene treatment enhances brain activation during recognition of familiar items: a pharmacological fMRI study in healthy elderly males. Neuropsychopharmacology 2006;31:1508-1518. [PubMed: 16292319]

9. Berman KF, Schmidt PJ, Rubinow DR, Danaceau MA, Van Horn JD, Esposito G, Ostrem JL, Weinberger DR. Modulation of cognition-specific cortical activity by gonadal steroids: a positronemission tomography study in women. Proc Natl Acad Sci USA 1997;94:8836-8841. [PubMed: 9238064]

10. Shumaker SA, Legault C, Thal L, Wallace RB, Ockene JK, Hendrix SL, Jones BN III, Assaf AR, Jackson RD, Kotchen JM, Wassertheil-Smoller S, Wactawski-Wende J. Estrogen plus progestin and the incidence of dementia and mild cognitive impairment in postmenopausal women: the Women's Health Initiative Memory Study: a randomized controlled trial. JAMA 2003;289:2651-2662. [PubMed: 12771112]

11. Heldring N, Pike A, Andersson S, Matthews J, Cheng G, Hartman J, Tujague M, Strom A, Treuter E, Warner M, Gustafsson J-A. Estrogen receptors: how do they signal and what are their targets. Physiol Rev 2007;87:905-931. [PubMed: 17615392]

12. Shughrue PJ, Stumpf WE, MacLusky NJ, Zielinski JE, Hochberg RB. Developmental changes in estrogen receptors in mouse cerebral cortex between birth and postweaning: studied by autoradiography with 11 beta-methoxy-16 alpha-[125I]iodoestradiol. Endocrinology 1990;126:1112-1124. [PubMed: 2298154]

13. Pfaff D, Keiner M. Atlas of estradiol-concentrating cells in the central nervous system of the female rat. J Comp Neurol 1973;151:121-158. [PubMed: 4744471]

14. Pau CY, Pau KY, Spies HG. Putative estrogen receptor beta and alpha mRNA expression in male and female rhesus macaques. Mol Cell Endocrinol 1998;146:59-68. [PubMed: 10022763]

15. Perlman WR, Tomaskovic-Crook E, Montague DM, Webster MJ, Rubinow DR, Kleinman JE, Weickert CS. Alteration in estrogen receptor alpha mRNA levels in frontal cortex and hippocampus of patients with major mental illness. Biol Psychiatry 2005;58:812-824. [PubMed: 16112656]

16. Shughrue PJ, Lane MV, Merchenthaler I. Comparative distribution of estrogen receptor-alpha and beta mRNA in the rat central nervous system. J Comp Neurol 1997;388:507-525. [PubMed: 9388012]

17. Perlman WR, Matsumoto M, Beltaifa S, Hyde TM, Saunders RC, Webster MJ, Rubinow DR, Kleinman JE, Weickert CS. Expression of estrogen receptor alpha exon-deleted mRNA variants in the human and non-human primate frontal cortex. Neuroscience 2005;134:81-95. [PubMed: 15964702]

18. Bollig A, Miksicek RJ. An estrogen receptor-alpha splicing variant mediates both positive and negative effects on gene transcription. Mol Endocrinol 2000;14:634-649. [PubMed: 10809228]

19. Kleinman, JE.; Hyde, TM.; Herman, MM. Methodological issues in the neuropathology of mental illness. In: Bloom, F.; Kupfer, DJ., editors. Psychopharmacology: The Fourth Generation of Progress. New York, NY: Raven Press, Ltd; 1995. p. 859-864.

20. Bevitt DJ, Milton ID, Piggot N, Henry L, Carter MJ, Toms GL, Lennard TW, Westley B, Angus B, Horne $\mathrm{CH}$. New monoclonal antibodies to oestrogen and progesterone receptors effective for paraffin section immunohistochemistry. J Pathol 1997;183:228-232. [PubMed: 9390038]

21. Lu Y-P, Zeng M, Swaab DF, Ravid R, Zhou J-N. Colocalization and alteration of estrogen receptor[alpha] and -[beta] in the hippocampus in Alzheimer's disease. Hum Pathol 2004;35:275-280. [PubMed: 15017582] 
22. Taylor AH, Al-Azzawi F. Immunolocalisation of oestrogen receptor beta in human tissues. J Mol Endocrinol 2000;24:145-155. [PubMed: 10657006]

23. Poola I, Koduri S, Chatra S, Clarke R. Identification of twenty alternatively spliced estrogen receptor alpha mRNAs in breast cancer cell lines and tumors using splice targeted primer approach. J Steroid Biochem Mol Biol 2000;72:249-258. [PubMed: 10822014]

24. Mitra SW, Hoskin E, Yudkovitz J, Pear L, Wilkinson HA, Hayashi S, Pfaff DW, Ogawa S, Rohrer SP, Schaeffer JM, McEwen BS, Alves SE. Immunolocalization of estrogen receptor beta in the mouse brain: comparison with estrogen receptor alpha. Endocrinology 2003;144:2055-2067. [PubMed: 12697714]

25. Cardona-Gomez GP, DonCarlos L, Garcia-Segura LM. Insulin-like growth factor I receptors and estrogen receptors colocalize in female rat brain. Neuroscience 2000;99:751-760. [PubMed: 10974438]

26. Mukai H, Tsurugizawa T, Murakami G, Kominami S, Ishii H, Ogiue-Ikeda M, Takata N, Tanabe N, Furukawa A, Hojo Y, Ooishi Y, Morrison JH, Janssen WGM, Rose JA, Chambon P, Kato S, Izumi S, Yamazaki T, Kimoto T, Kawato S. Rapid modulation of long-term depression and spinogenesis via synaptic estrogen receptors in hippocampal principal neurons. J Neurochem 2007;100:950-967. [PubMed: 17266735]

27. González M, Cabrera-Socorro A, Pérez-García CG, Fraser JD, López FJ, Alonso R, Meyer G. Distribution patterns of estrogen receptor $\alpha$ and $\beta$ in the human cortex and hippocampus during development and adulthood. J Comp Neurol 2007;503:790-802. [PubMed: 17570500]

28. Kruijver FP, Balesar R, Espila AM, Unmehopa UA, Swaab DF. Estrogen receptor-alpha distribution in the human hypothalamus in relation to sex and endocrine status. J Comp Neurol 2002;454:115139. [PubMed: 12412138]

29. Milner TA, McEwen BS, Hayashi S, Li CJ, Reagan LP, Alves SE. Ultrastructural evidence that hippocampal alpha estrogen receptors are located at extranuclear sites. J Comp Neurol 2001;429:355371. [PubMed: 11116225]

30. Adams MM, Fink SE, Shah RA, Janssen WG, Hayashi S, Milner TA, McEwen BS, Morrison JH. Estrogen and aging affect the subcellular distribution of estrogen receptor-alpha in the hippocampus of female rats. J Neurosci 2002;22:3608-3614. [PubMed: 11978836]

31. Wang Z, Zhang X, Shen P, Loggie BW, Chang Y, Deuel TF. Identification, cloning, and expression of human estrogen receptor-[alpha]36, a novel variant of human estrogen receptor-[alpha]66. Biochem Biophys Res Commun 2005;336:1023-1027. [PubMed: 16165085]

32. Stirone C, Duckles SP, Krause DN. Multiple forms of estrogen receptor-alpha in cerebral blood vessels: regulation by estrogen. Am J Physiol Endocrinol Metab 2003;284:E184-E192. [PubMed: 12388160]

33. Marin R, Ramirez CM, Gonzalez M, Alonso R, Diaz M. Alternative estrogen receptors homologous to classical receptor alpha in murine neural tissues. Neurosci Lett 2006;395:7-11. [PubMed: 16288833]

34. Coleman KM, Dutertre M, El-Gharbawy A, Rowan BG, Weigel NL, Smith CL. Mechanistic differences in the activation of estrogen receptor-alpha (ERalpha)- and ERbeta-dependent gene expression by cAMP signaling pathway(s). J Biol Chem 2003;278:12834-12845. [PubMed: 12566449]

35. Pasqualini C, Guivarc'h D, Boxberg YV, Nothias F, Vincent JD, Vernier P. Stage- and region-specific expression of estrogen receptor alpha isoforms during ontogeny of the pituitary gland. Endocrinology 1999;140:2781-2789. [PubMed: 10342869]

36. Friend KE, Resnick EM, Ang LW, Shupnik MA. Specific modulation of estrogen receptor mRNA isoforms in rat pituitary throughout the estrous cycle and in response to steroid hormones. Mol Cell Endocrinol 1997;131:147-155. [PubMed: 9296373]

37. Flouriot G, Brand H, Denger S, Metivier R, Kos M, Reid G, Sonntag-Buck V, Gannon F. Identification of a new isoform of the human estrogen receptor-alpha (hER-alpha) that is encoded by distinct transcripts and that is able to repress hER-alpha activation function 1. EMBO J 2000;19:4688-4700. [PubMed: 10970861]

38. Prewitt AK, Wilson ME. Changes in estrogen receptor-alpha mRNA in the mouse cortex during development. Brain Res 2007;1134:62-69. [PubMed: 17207781] 
39. Kritzer MF, Kohama SG. Ovarian hormones differentially influence immunoreactivity for dopamine beta- hydroxylase, choline acetyltransferase, and serotonin in the dorsolateral prefrontal cortex of adult rhesus monkeys. J Comp Neurol 1999;409:438-451. [PubMed: 10379829]

40. Tang Y, Janssen WGM, Hao J, Roberts JA, McKay H, Lasley B, Allen PB, Greengard P, Rapp PR, Kordower JH, Hof PR, Morrison JH. Estrogen replacement increases spinophilin-immunoreactive spine number in the prefrontal cortex of female rhesus monkeys. Cereb Cortex 2004;14:215-223. [PubMed: 14704219]

41. Hao J, Rapp PR, Leffler AE, Leffler SR, Janssen WGM, Lou W, McKay H, Roberts JA, Wearne SL, Hof PR, Morrison JH. Estrogen alters spine number and morphology in prefrontal cortex of aged female rhesus monkeys. J Neurosci 2006;26:2571-2578. [PubMed: 16510735]

42. Toran-Allerand CD. Estrogen and the brain: beyond ER-alpha and ER-beta. Exp Gerontol 2004;39:1579-1586. [PubMed: 15582272]

43. Prossnitz ER, Arterburn JB, Sklar LA. GPR30: a G protein-coupled receptor for estrogen. Mol Cell Endocrinol 2007;266:138-142. [PubMed: 17222505]

44. DeArmond, SJ.; Fusco, MM.; Dewey, MM. Structure of the Human Brain: A Photographic Atlas. New York, NY: Oxford University Press; 1989.

45. Paxinos, G.; Huang, X-F.; Toga, AW. The Rhesus Monkey Brain in Stereo-taxic Coordinates. San Diego, CA: Academic Press; 2000.

46. Paxinos, G.; Watson, C. The Rat Brain in Stereotaxic Coordinates. Sydney: Academic Press; 1997. 
(A)

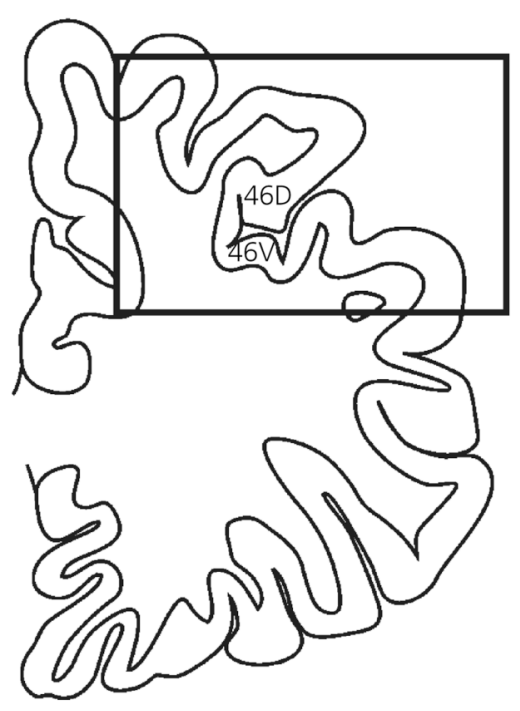

Human
(B)

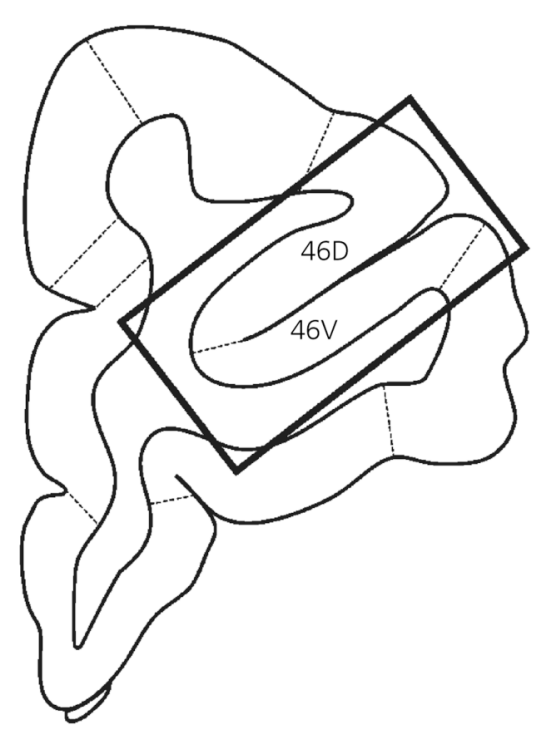

Monkey
(C)

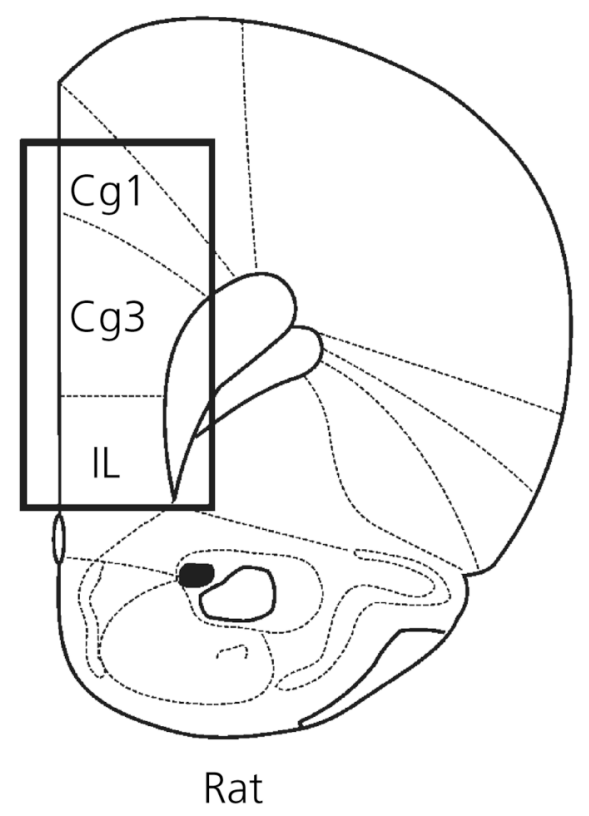

Fig. 1.

(A-C) Outline of coronal sections though the human, monkey, and rat frontal cortex. The boxed area represents the area examined for each species. (A) coronal slice through the frontal lobe of the human brain, the boxed area includes the superior frontal and middle frontal gyrus, Brodmann's area 46 of the dorsolateral prefrontal cortex $(\mathrm{D}$, dorsal; V, ventral) is marked (45); (B) coronal slice (Bregma's coordinates 18.18-15.30 mm) though the monkey frontal lobe, the boxed area includes the upper and lower banks of the principle sulcus, with Brodmann's area 46 marked (46); (C) coronal slice (Bregma's coordinates 3.20-2.70 mm) through the frontal cortex of the rat, the boxed area represents the medial frontal cortex, with the infralimbic cortex (IL) and cingulate cortex areas 1 and 3 (Cg1 and Cg3) marked (47). 

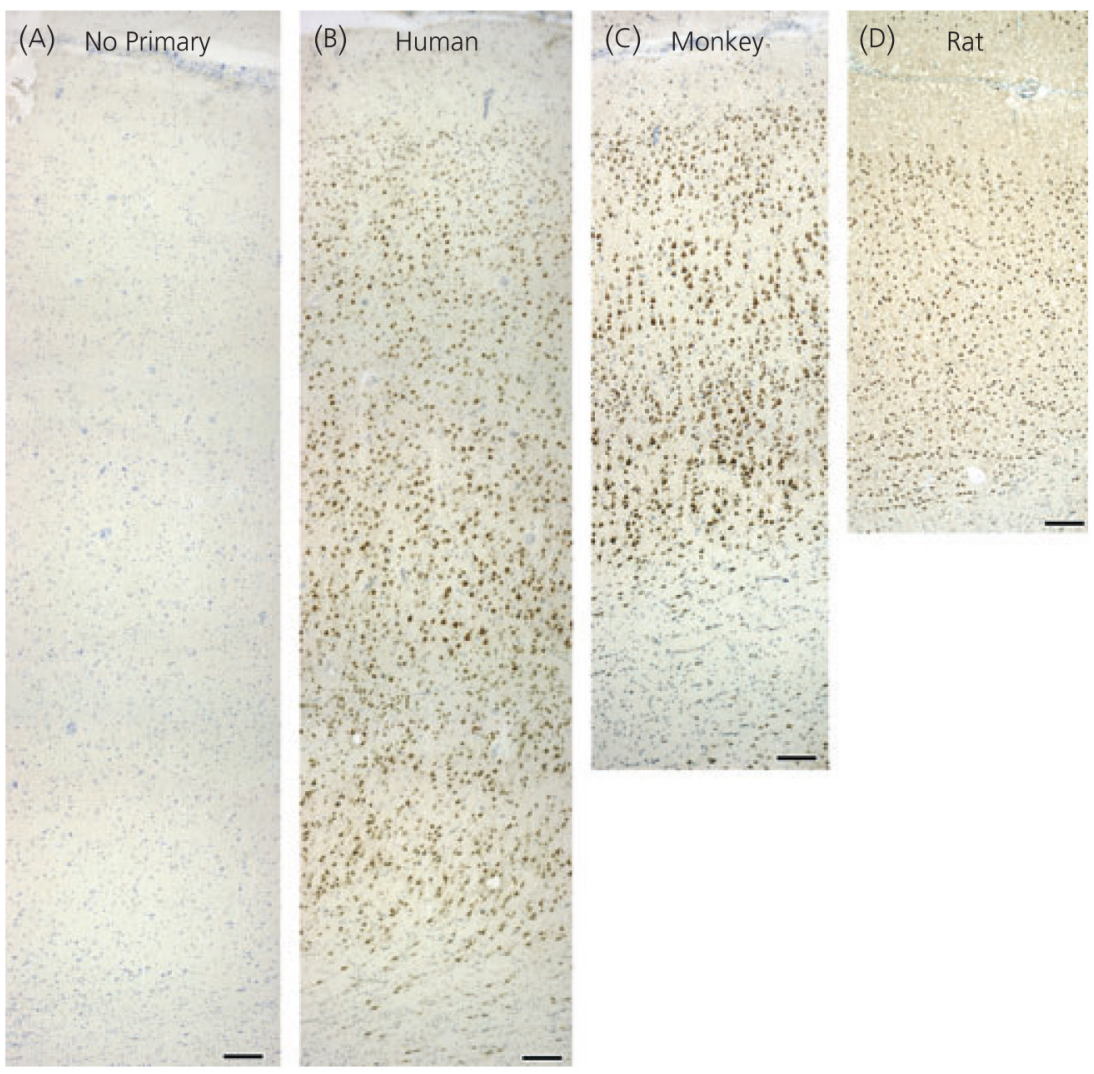

Fig. 2.

(A-D). Photomicrographs of tissue sections after immunohistochemistry with the antioestrogen receptor (ER) $\alpha$ antibody (B-D) showing robust immunolabel in the prefrontal cortex of human, monkey and rat subjects. (A) In the absence of ER $\alpha$ antibody, no immunolabelling (brown reaction product) is observed in human dorsolateral prefrontal cortex (DLPFC).

Labelling in the absence of $\mathrm{ER} \alpha$ antibody in monkey and rat PFC display similar results (data not shown). (B-D) Anti-ER $\alpha$ labelling is present throughout all layers of the prefrontal cortex. (B) Robust ER $\alpha$ immunolabelling of cells of the human DLPFC is seen in layers II-VI and in scattered cells in the subcortical white matter; (C) Robust ER $\alpha$ immunolabelling in monkey DLPFC is found in all neuronal layers; (D) Robust ER $\alpha$ immunolabelling is found in rat medial PFC. ER $\alpha$ protein localisation, indicated by brown staining.. Thionin, a Nissl stain, was used to visualise the cytoarchitectural structure of the prefrontal cortex (blue staining) and reveals that glial cells (dark blue Nissl) do not show a brown reaction product. Scale bar $=200 \mu \mathrm{m}$. 

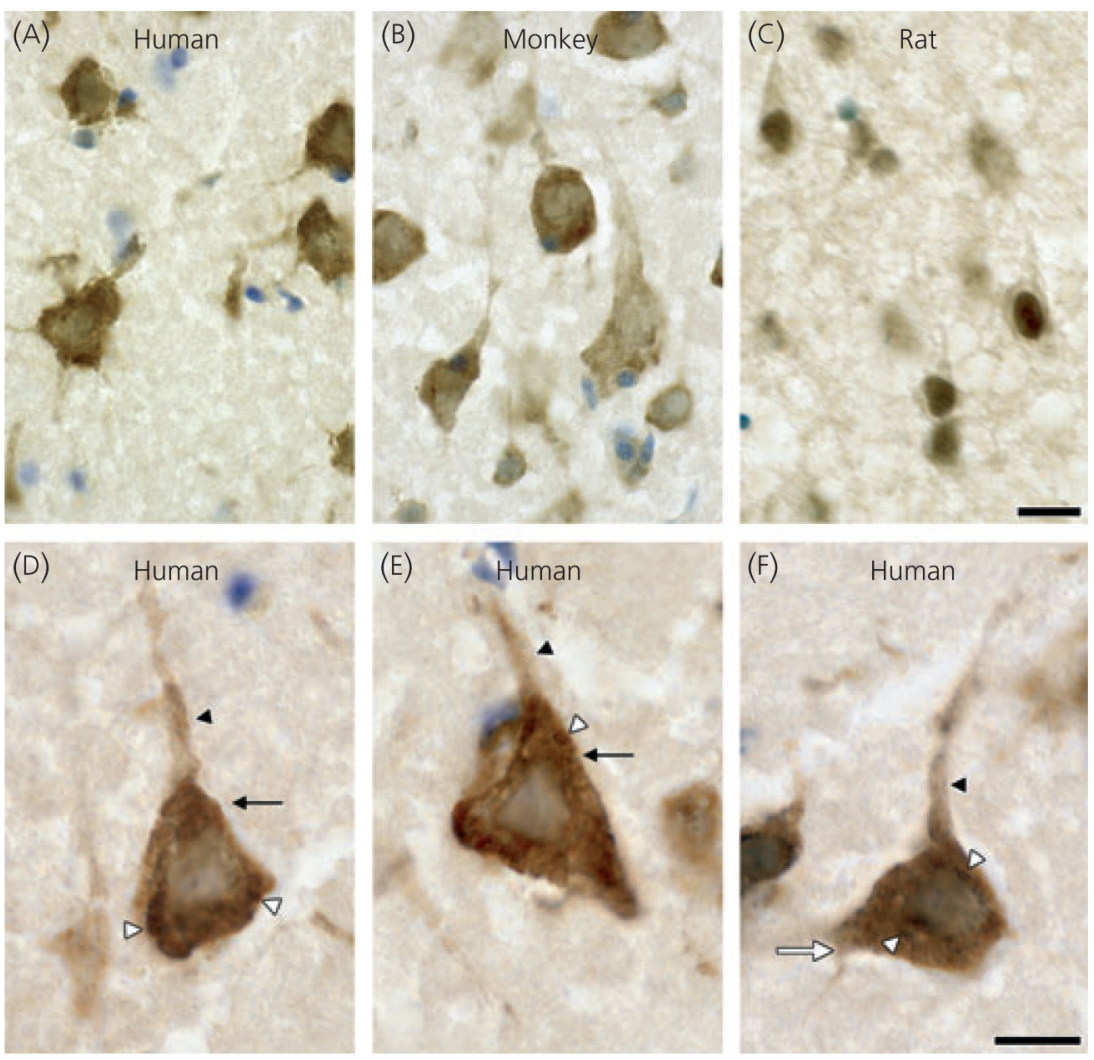

Fig. 3.

(A-F). A higher magnification of neurones in prefrontal cortex (PFC) displays the subcellular distribution of oestrogen receptor (ER) $\alpha$. (A-C) Anti-ER $\alpha$ immunolabelling is observed in the cytoplasmic and nuclear areas of neurones in the prefrontal cortex of all three species but not in Nissl stained glia cells. ER $\alpha$ labelling in layer V of human and monkey dorsolateral (DL) PFC and layer $V$ of rat medial PFC. (A) In the human DLPFC punctuate immunoreactivity can be seen in the cell soma and cellular processes of neurones; (B) In the monkey DLPFC, uneven immunoreactivity can be detected in the cell soma and extends into the apical dendrites of neurones; (C) In the rat PFC, nuclear ER $\alpha$ immunoreactivity is predominate, although some label is seen in the cytoplasm. Scale bar $=25 \mu \mathrm{m}$ and is representative of (A-C). (D-F) ER $\alpha$ distribution is not homogeneous in every neurone in human DLPFC. Variation in the intensity and apparent subcellular distribution of ER $\alpha$ immunolabelling in pyramidal neurones of layer $\mathrm{V}$ is seen. ER $\alpha$ labelling in the cytoplasm appears darker than the nucleus in some neurones (D-E, black arrow), clumps of immunoreactivity can be found along the outer cell membrane (D, white arrowheads), whereas perinuclear (white arrowheads in F) and nuclear staining is intense in other neurones. In all three neurones photographed, immunolabelling extends to the apical dendrite (black arrowheads). There is also some ER $\alpha$ labelling extending into the basilar dendrites (F, white arrow). Scale bar $=10 \mu \mathrm{m}$ and is representative of (D-F). 

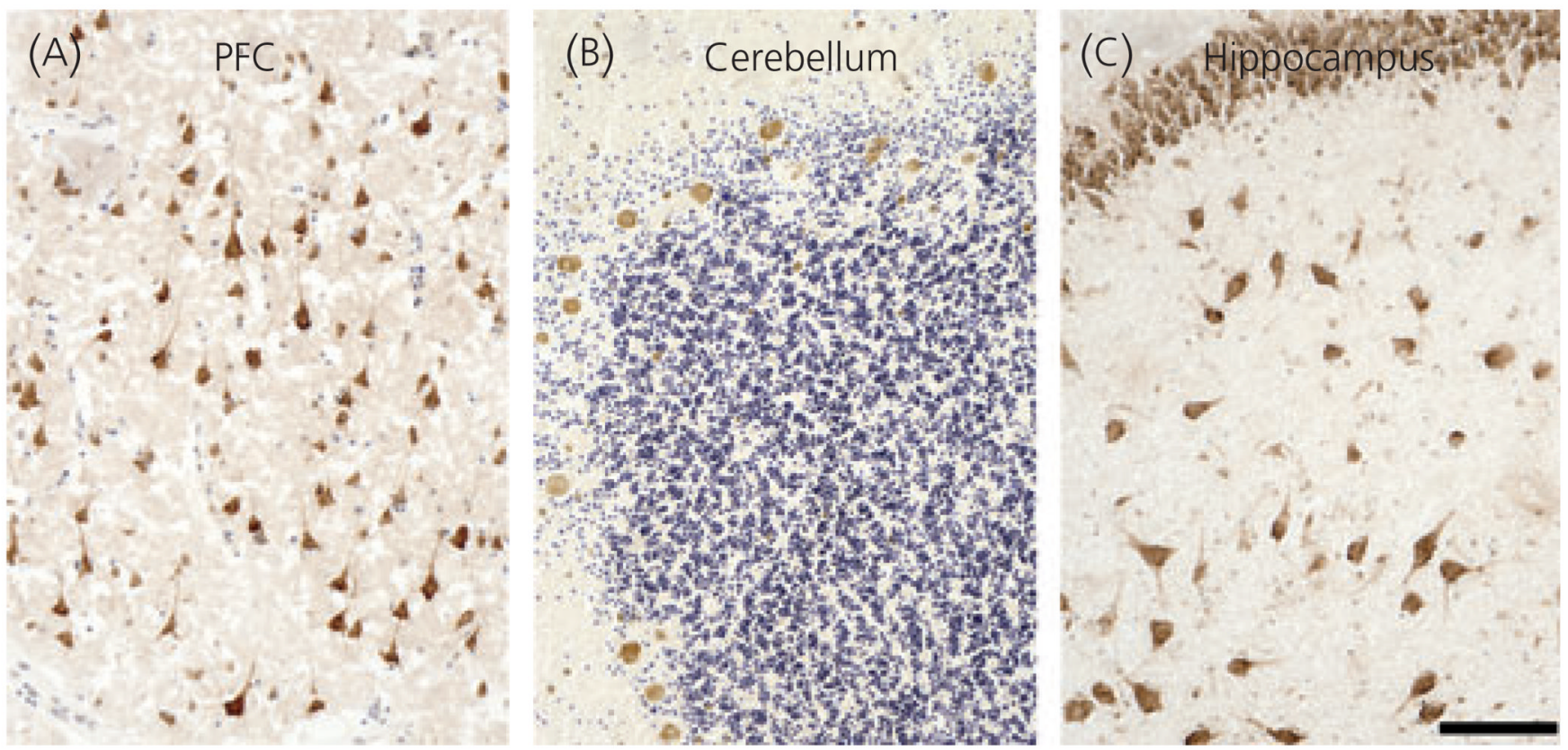

Fig. 4.

$(A-C)$. Oestrogen receptor (ER) $\alpha$ immunolocalisation in human dorsolateral prefrontal cortex (DLPFC), hippocampus, and cerebellum varies in intensity. ER $\alpha$ immunolabelling in layer III of the DLPFC is intense in the cytoplasm of pyramidal neurones and extends into the apical and basilar dendrites. (A) Light immunoreactivity is found in the cytoplasm of Purkinje cells and Golgi cells of the human cerebellum; (B) robust immunoreactivity in cytoplasm and processes of neurones in the hilar (CA4) and dentate gyrus regions of the human hippocampus; (C) scale bar $=150 \mu \mathrm{m}$. 


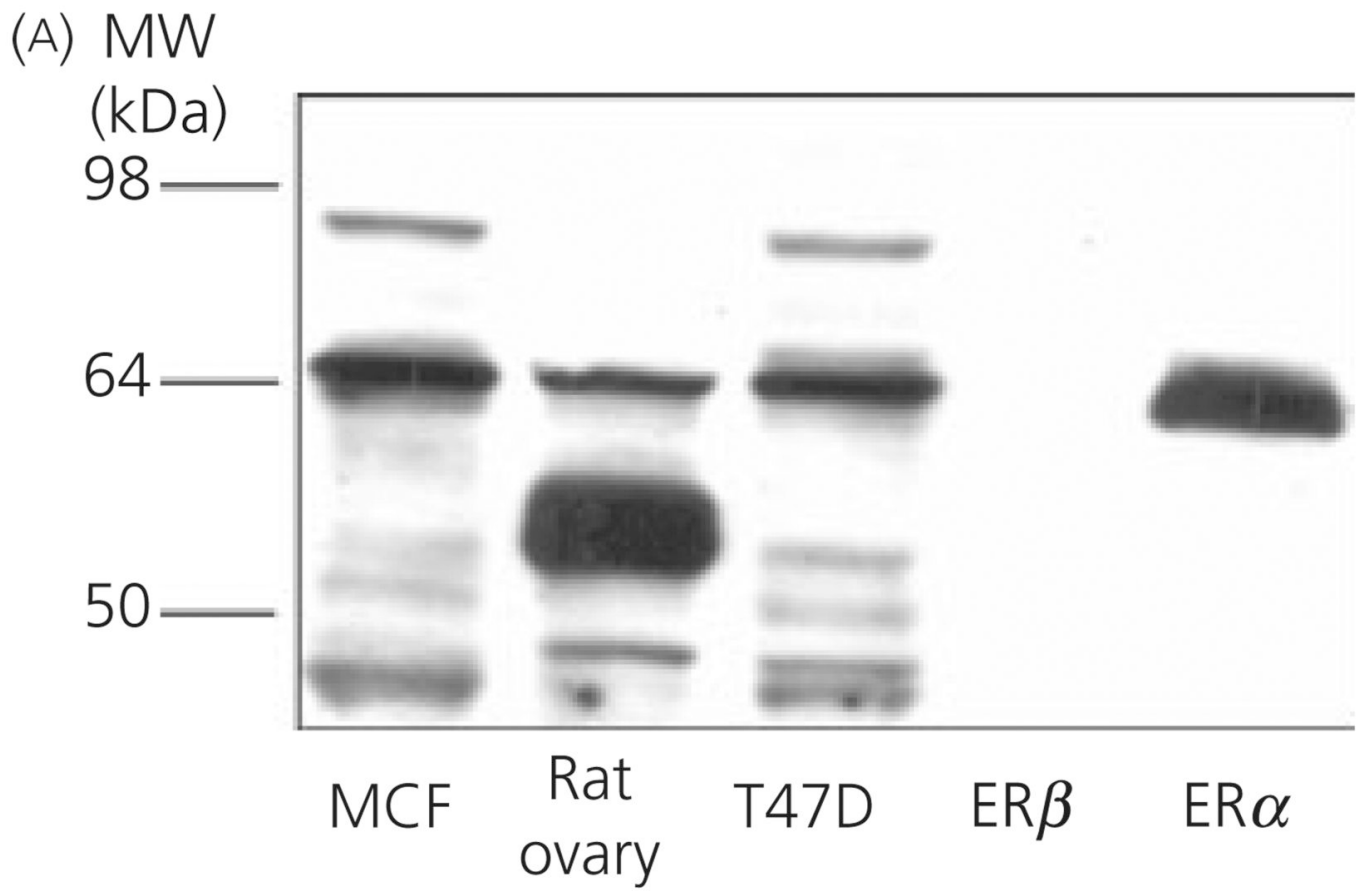

(B) $\mathrm{MW}$

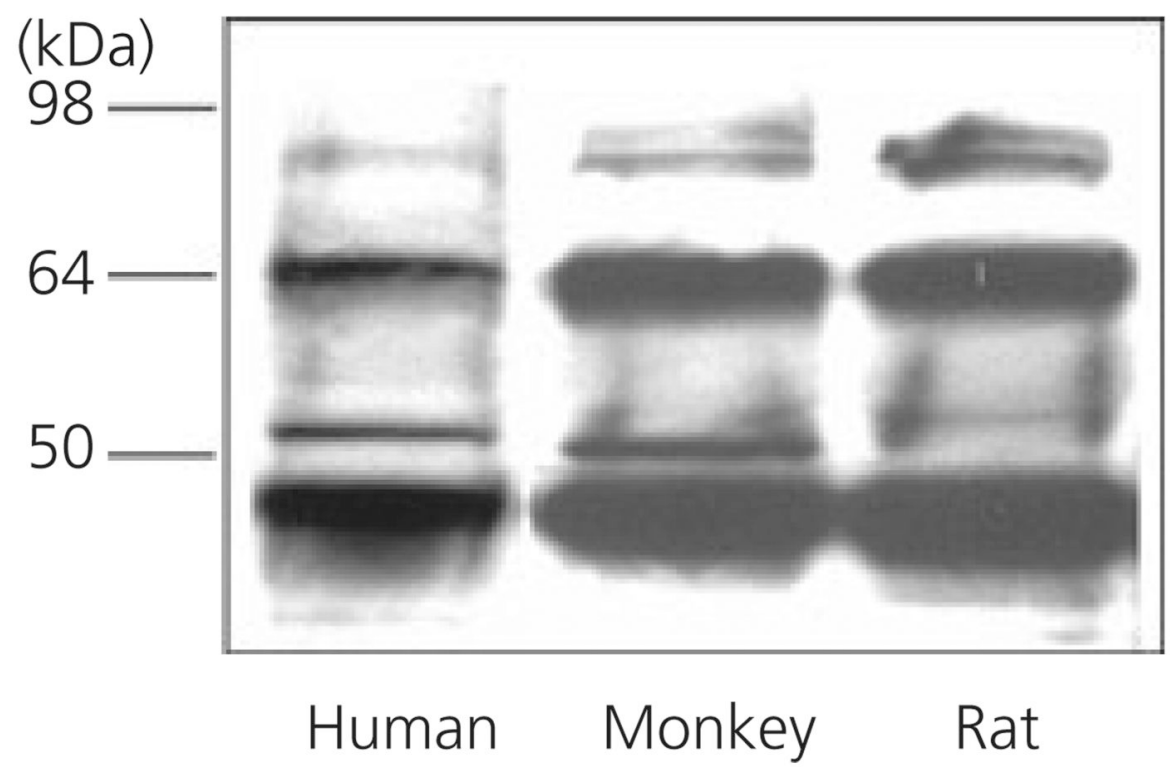

Fig. 5.

(A-B) Western blot analysis reveals the expression of the full-length oestrogen receptor (ER) $\alpha$ protein in prefrontal cortical tissue. (A) The ER $\alpha$ antibody is specific for ER $\alpha$ and does not recognise ER $\beta$. Novocastra ER6F11 detects the expected ER $\alpha$ protein expression in the MCF7 cell lysate (lane 1), rat ovary (lane 2), T47D cell lysate (lane 3) and the full-length recombinant $\mathrm{ER} \alpha$ (lane 5). The band at approximately $65-67 \mathrm{kDa}$ is consistent with the classical full-length $\mathrm{ER} \alpha$ protein and can be detected in all lanes except in the lane where only recombinant ER $\beta$ was present (lane 4). Lower molecular weight bands which vary in intensity according to the sample are detected by the anti-ER $\alpha$ antibody (at 55 and $45 \mathrm{kDa}$ ), as well as one higher molecular weight immunoreactive band $(94 \mathrm{kDa})$. Molecular weight size markers in $\mathrm{kDa}$ are 
shown to the left of the figure. (B) Full-length ERa immunopositive proteins as well as smaller $\mathrm{ER} \alpha$ immunoreactive proteins are expressed in the prefrontal cortex of all three species.

Novocastra ER6F11was used to characterise ER $\alpha$ immunopositive proteins in the cytoplasmic fractions from human, monkey and rat prefrontal cortical tissue. The band at approximately 65-67 kDa corresponds to the full-length ER $\alpha$ protein. The additional bands detected by the antibody suggest additional ER $\alpha$-like proteins identified with Novocastra ER6F11 in brain may overlap with those detected in other tissues and cell lines (approximately 94, 51 and 45-48 $\mathrm{kDa}$ ). Molecular weight size markers in $\mathrm{kDa}$ are shown to the left. 

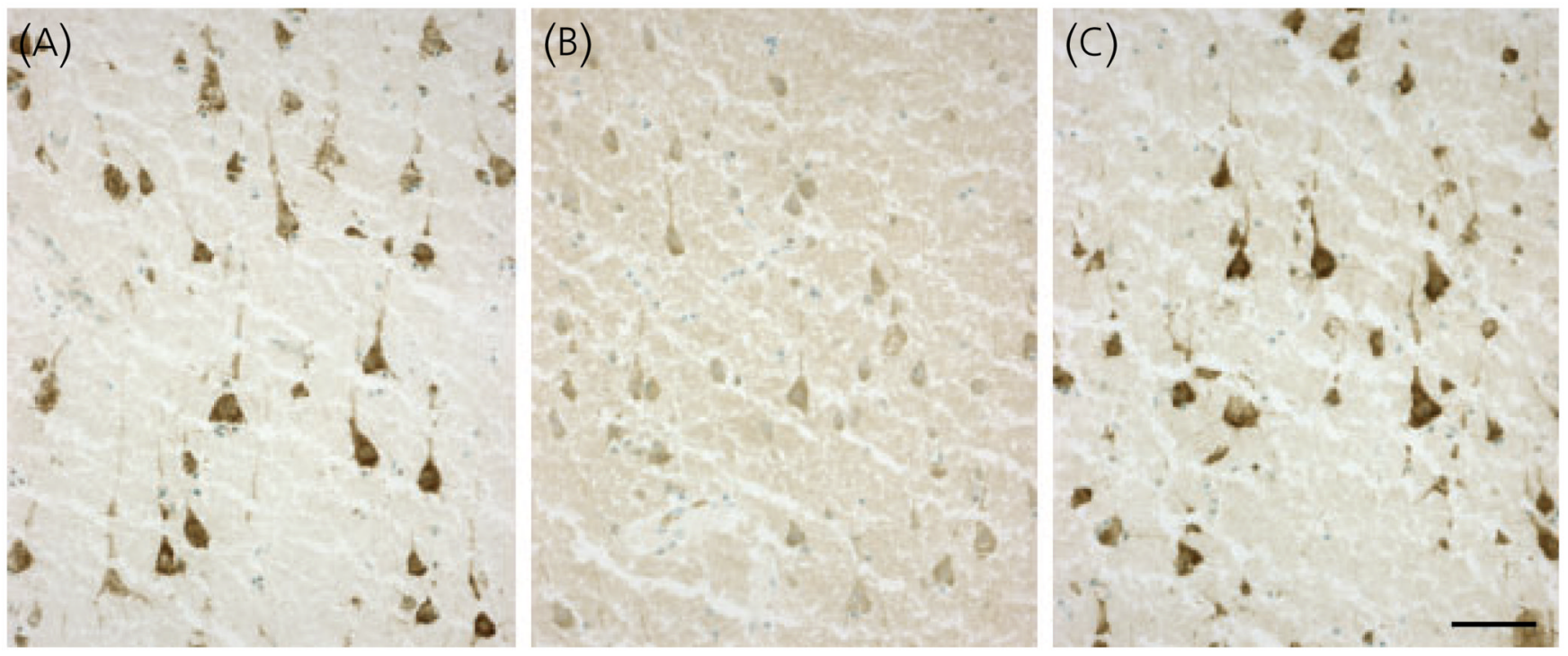

(D)

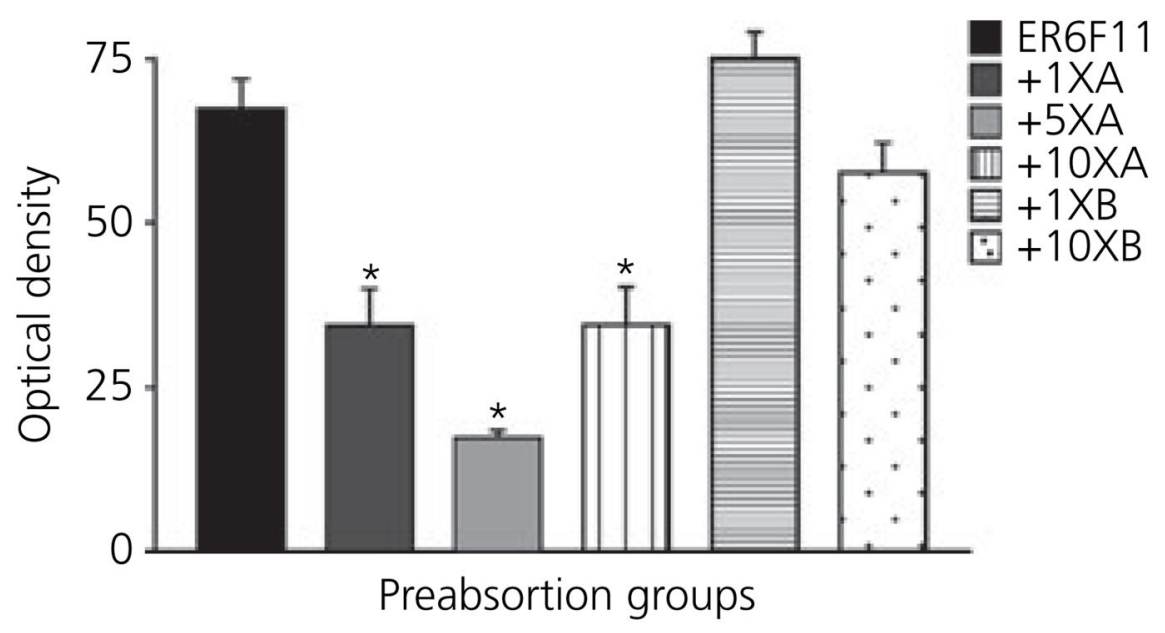

Fig. 6.

(A-D) Immunohistochemistry after antibody preabsorption with full-length oestrogen receptor (ER) $\alpha$ protein diminishes ER $\alpha$ antibody labelling in human dorsolateral prefrontal cortex (DLPFC). The primary Novocastra ER6F11 antibody was preabsorbed overnight with fulllength ER $\alpha$ or full-length ER $\beta$. Immunohistochemistry was performed with these antibodyprotein mixtures on human DLPFC. (A) ER $\alpha$ antibody alone; (B) ER $\alpha$ antibody preabsorbed with $1 \times$ ER $\alpha$ protein; $(C)$ ERa antibody preabsorbed with $1 \times$ ER $\beta$ protein. Scale bar $=50 \mu \mathrm{m}$ in (A-C); (D) bar graph showing the intensity of ER6F11 labelling in the presence and absence of $\mathrm{ER} \alpha$ and $\mathrm{ER} \beta$ recombinant protein at $1: 1(\times 1), 1: 5(\times 5)$, and $1: 10(\times 10)$ molar concentrations of the ER6F11 primary antibody. The values in this graph represent the mean total immunolabelling (error bars indicate the SEM). Overall ANOva shows a significant block of immunolabel at all three concentrations of ER $\alpha$ protein $(\times 1, \times 5$ and $\times 10)(F=42.972$, d.f. $=6,53, * \mathrm{P}<0.005)$. Immunohistochemistry with protein blocking was performed in monkey and rat prefrontal cortex with similar results (data not shown). 
Table 1

Frozen DLPFC Post-Mortem Blocks were Obtained as Described in the Materials and Methods.

Subject characteristics for human post-mortem normal controls

\begin{tabular}{lllll}
\hline Subject & $\begin{array}{l}\text { Age } \\
\text { (years) }\end{array}$ & Ethnicity/gender & PMI (h) & Cause of death \\
\hline 1 & 51 & AA/M & 6.5 & Pneumonia \\
2 & 41 & AA/M & 14.5 & SW \\
3 & 40 & C/M & 16 & ASCVD \\
4 & 34 & AA/M & 13.5 & GSW \\
5 & 43 & AA/M & 23 & Hypertrophic Cardiomyopathy \\
6 & 42 & AA/M & 27.5 & SW \\
7 & 49 & AA/M & 50.5 & Diabetic Ketoacidosis \\
\hline
\end{tabular}

PMI, post-mortem interval; AA, African-American; C, Caucasian; M, Male; GSW, gun shot wound; SW, stab wound; ASCVD, atherosclerotic cardiovascular disease 